\title{
Two dimensional protein patterns of bronchoalveolar lavage fluid from non-smokers, smokers, and subjects exposed to asbestos
}

\author{
Mats Lindahl, Tommy Ekström, Jan Sörensen, Christer Tagesson
}

Department of Occupational and Environmental

Medicine

$M$ Lindahl

C Tagesson

Department of Pulmonary Medicine T Ekström

Department of Anesthesiology

J Sörensen

University of Linköping, Faculty of Health Sciences, S-581 85 Linköping, Sweden

Correspondence to: Dr M Lindahl.

Received 10 November 1995 Returned to authors

Returned to auth

20 January 1996

1 March 1996

Accepted for publication

Accepted for public

\begin{abstract}
Background - Bronchoalveolar lavage (BAL) fluid contains a large number of proteins which comprise a potential resource for studying respiratory effects due to occupational and environmental exposures. A study was undertaken to compare protein patterns of BAL fluid from nonsmokers, smokers, and subjects exposed to asbestos.

Methods - BAL fluid samples were analysed with two dimensional gel electrophoresis (2-DE). The separated proteins were detected, quantified, and patternmatched between different individuals with a computerised imaging system designed for evaluations of 2-DE patterns.

Results - About 200 different protein spots were detected in each sample of BAL fluid. As is the case with blood plasma, the BAL fluid samples contained large amounts of albumin, transferrin, and immunoglobulins. Higher levels of basic proteins were found in smokers than in non-smokers, while subjects exposed to asbestos had increased amounts of several high molecular weight proteins as well as basic proteins. Lower levels of albumin and higher levels of immunoglobulins were found in smokers than in nonsmokers, while higher levels of transferrin were found in asbestos exposed subjects than in unexposed subjects. Moreover, in the group exposed to asbestos differences were found between patients with pleuritis and patients with pleural plaque, and one protein spot was found only in two patients with progressive pleural disease.

Conclusion - These results suggest that both smokers and asbestos exposed subjects have significant changes in their airway protein expression compared with non-smokers and unexposed subjects. It is inferred that analysis of protein patterns in the BAL fluid with 2-DE may be used to detect and characterise, at a molecular level, respiratory effects due to occupational and environmental exposures. (Thorax 1996;51:1028-1035)
\end{abstract}

Keywords: bronchoalveolar lavage fluid, two dimensional gel electrophoresis, asbestos.

Bronchoalveolar lavage (BAL) fluid has been used to investigate cellular and biochemical components of the airways in diseases such as asthma, ${ }^{1}$ sarcoidosis, ${ }^{2}$ and septic shock, ${ }^{3}$ and the possibility of performing BAL for diagnostic and clinical purposes has been discussed. ${ }^{4}$ Accordingly, BAL fluid has been utilised for differential cell counting, for assessment of specific inflammatory mediators, and for verification of occupational exposures. ${ }^{56}$ However, the airways contain a large number of proteins which altogether comprise a potential resource for detection and characterisation of the different effects that may develop after occupational and environmental exposures to noxious agents. As yet, this possibility has been little investigated, partly because of difficulties in the separation and evaluation of these various proteins.

Two dimensional gel electrophoresis (2-DE) is the separation of proteins according to charge (first dimension) and size (second dimension), leading to a protein spot pattern map. From the time it was first presented 2-DE has been regarded as the technique which gives the highest analytical resolution of proteins. ${ }^{7}$ This makes it a potentially powerful method of detecting early changes in protein patterns of extracellular fluids and thereby providing specific diagnostic information in various diseases. ${ }^{89}$ So far, however, 2-DE has been used mainly in experimental research rather than clinical studies. One reason for this is the problem of handling the huge mass of data that are generated when 2-DE patterns from many individuals are analysed. In recent years, however, computer systems have become available that can be used to evaluate 2-DE patterns and make it possible to compare results between individuals or groups of individuals. ${ }^{10}$ Although little is known about 2-DE patterns in human BAL fluid, recent studies on BAL fluid and nasal lavage fluid from patients with asthma and pulmonary fibrosis suggest that 2-DE analysis may be useful for investigating pathological alterations of the airways. ${ }^{112}$ In the present study BAL fluid samples from nonsmokers, smokers, and subjects exposed to asbestos were analysed and evaluated with a computerised imaging system designed for 2-DE protein mapping.

\section{Methods}

PATIENTS

The study comprised 12 patients and 18 healthy volunteers. The patients (aged 44-66 years, all men, five non-smokers, six smokers, and one ex-smoker) were referred to the pulmonary department after previous exposure to asbestos. They were subjected to bron- 
choalveolar lavage, radiographic examination, and spirometric testing. Pleural plaques alone were found in seven patients while five were diagnosed as having asbestos pleuritis with massive pleural thickening and shrinkage of lung parenchyma (hyalinosis complicata). In the group with pleural plaque the mean vital capacity (VC) was $92 \%$ of predicted (range $74-103 \%$ ), and in the group with pleuritis the mean value was $66 \%$ of predicted (range $55-78 \%$ ). In 10 patients it was also possible to carry out follow up radiographic examination and spirometric tests after four years, at which time the predicted VC had decreased by $4 \%$ in the group with pleural plaques and by $9 \%$ in those with pleuritis. The second radiographic examination showed that one patient had progressive pleural plaques and one a progressive pleuritis.

The healthy volunteers (aged 24-42 years, 11 men and seven women, nine smokers and nine non-smokers) had no history or present symptoms of pulmonary disease or dysfunction. $^{3}$

\section{BRONCHOALVEOLAR LAVAGE PROCEDURE}

Bronchoalveolar lavage (carried out with the informed consent of the subjects concerned and approved by the ethical committee of the Medical Faculty, University of Linköping) was performed in 12 patients and 18 healthy individuals. The procedure was carried out by the same bronchoscopist in all cases. After premedication with diazepam $(2.5-5.0 \mathrm{mg})$ and morphine (2.5-7.5 mg), bronchoscopic examination was performed under local anaesthesia and with a nasal oxygen supply at a rate of 6 $1 / \mathrm{min}$. A flexible fibreoptic bronchoscope was positioned in a subsegmental bronchus of the right middle or lower lobe, and $20 \mathrm{ml}$ aliquots (total volume $140-180 \mathrm{ml}$ ) of sterile isotonic phosphate buffer $\left(37^{\circ} \mathrm{C}, \mathrm{pH} 7.4\right)$ were instilled into the peripheral area and then aspirated using low pressure suction $(8-10 \mathrm{kPa})$. The BAL fluid was collected in siliconised tubes and immediately put on ice. The mean (SE) recovery of BAL fluid was 55 (4)\%. Five ml of the BAL fluid was transferred into EDTA tubes for differential cell counting and the remaining fluid was filtered through a $100 \mu \mathrm{m}$ nylon filter, centrifuged at $400 \mathrm{~g}$ for 15 minutes to remove cells, and the supernatant was frozen in liquid nitrogen and stored at $-70^{\circ} \mathrm{C}$.

\section{SAMPLE PREPARATION}

The protein concentration in the BAL fluid was determined by Bio-Rad protein assay according to the method of Bradford. ${ }^{13}$ The samples were then prepared for 2-DE by adding final concentrations of $5 \mathrm{M}$ urea, $44 \%(\mathrm{v} / \mathrm{v})$ glycerol, 3\% (v/v) NP-40, 0.3\% (w/v) SDS, 60 $\mathrm{mM}$ DTT, $1.9 \%(\mathrm{v} / \mathrm{v})$ ampholine 5-7, and $1.9 \%(\mathrm{v} / \mathrm{v})$ ampholine 8-9.5. The 2-DE samples were stored at $-20^{\circ} \mathrm{C}$ until analysed.

TWO DIMENSIONAL ELECTROPHORETIC PROCEDURE

The 2-DE procedure used was essentially based on the one previously described by $\mathrm{O}^{\prime}$ Farrell ${ }^{7}$ and Celis. ${ }^{14}$ Isoelectric focusing was performed in gel rods with a length of $100 \mathrm{~mm}$ and a diameter of $3 \mathrm{~mm}$ containing an acrylamide concentration of $\mathrm{T}=4 \%, \mathrm{C}=5.5 \% .{ }^{15} \mathrm{~A}$ non-linear $\mathrm{pH}$ gradient from 4 to 9 was generated by including $4 \%(\mathrm{v} / \mathrm{v})$ of carrier ampholytes (Pharmacia-LKB, Solna, Sweden). The composition of the ampholytes was selected to obtain optimal resolution in $\mathrm{pH}$ region $5-7$, but the gradient was also reinforced in the basic region $(33 \% \mathrm{pH} 5-7,33 \% \mathrm{pH} 3-10,33 \%$ $\mathrm{pH}$ 8-9.5). To ensure a reproducible $\mathrm{pH}$ profile, however, the ampholyte composition was modified slightly during the course of the study due to batch variations of the ampholytes. The $\mathrm{pH}$ gradient profile was determined by measuring the $\mathrm{pH}$ of sliced tube gel fractions $(5 \mathrm{~mm})$ extracted with $0.25 \mathrm{ml} \mathrm{H}_{2} \mathrm{O}$ and comparing with isoelectric point (pI) standards (acetylated cytochrome c from Calbiochem, San Diego, California, USA). After prefocusing of the gels, the BAL fluid sample (5 $\mu \mathrm{g}$ protein) was applied and the isofocusing run overnight at $400 \mathrm{~V}+800 \mathrm{~V}$ during the last hour (totalling 6830 V.h) with cooling $\left(8^{\circ} \mathrm{C}\right) \cdot .^{14}$

In the second dimension the gel rods were equilibrated, transferred to polyacrylamide gels, and sealed with $1 \%(\mathrm{w} / \mathrm{v})$ agarose. ${ }^{14}$ Discontinuous SDS-polyacrylamide gel electrophoresis (SDS-PAGE) was carried out in slab gels $(160 \times 130 \mathrm{~mm})$, as described by Laemmli, ${ }^{16}$ in acrylamide concentration gradients $\mathrm{T}=5-18 \%, \mathrm{C}=1 \%$ containing a glycerol gradient from 0 to $50 \% .{ }^{15}$ The gradient made it possible to separate proteins of a molecular mass ranging from $5 \mathrm{kDa}$ to $400 \mathrm{kDa}$. To assess the molecular weight (MW) of the BAL fluid proteins parallel runs with molecular mass markers ranging from $14 \mathrm{kDa}$ to $200 \mathrm{kDa}$ (Bio-Rad, Richmond, California, USA) were carried out. The SDS-PAGE was run with cooling over night at approximately $200 \mathrm{~V}$ (total 4600 V.h).

To detect as many proteins as possible with different properties a wide $\mathrm{pH}$ gradient was used in the first dimension, separating proteins with a pI from 4 to 9 , and a wide acrylamide concentration gradient was used in the second dimension, separating proteins with molecular masses from 5 to $400 \mathrm{kDa}$. With these 2-DE gels about 200 protein spots were demonstrated in BAL fluids containing a total amount of $5 \mu \mathrm{g}$ protein. We have recently found even more spots in BAL fluid using $\mathrm{pH}$ gradients generated by immobilines instead of ampholytes and by using higher protein sample loading in combination with further improved silver staining protocols. ${ }^{11}$ It is therefore likely that the amount of information obtained by the 2-DE technique in this study, although complex, is not the limit. It is also possible that more spots would have been detected with narrower gradients, giving better resolution of acidic proteins with molecular weights between 30 and $90 \mathrm{kDa}$, but the use of these types of gradients may result in both basic proteins and low and high molecular weight proteins being lost from the 2-DE patterns. The results of the present study, in which increased amounts of basic proteins were found in smokers and 
Table 1 Mean (SE) differential cell counts in bronchoalveolar lavage fluids from unexposed non-smokers $(n=9)$, unexposed smokers $(n=9)$, asbestos exposed non-smokers $(n=5)$ and asbestos exposed smokers $(n=6)$

\begin{tabular}{|c|c|c|c|c|}
\hline \multirow[b]{2}{*}{ Cell count } & \multicolumn{2}{|l|}{ Controls } & \multicolumn{2}{|c|}{ Asbestos exposed } \\
\hline & Non-smokers & Smokers & Non-smokers & Smokers \\
\hline Total $\left(10^{9} / 1\right)$ & $0.03(0.01)$ & $0.10(0.06)$ & $0.07(0.02)$ & $0.15(0.04)$ \\
\hline \multicolumn{5}{|l|}{ Distribution (\%) } \\
\hline Macrophages & $96(2)$ & $91(3)$ & $97(1)$ & $96(1)$ \\
\hline $\begin{array}{l}\text { Macrophages } \\
\text { (pigmented) }\end{array}$ & $0(0)$ & $54(11)$ & $4(2)$ & $50(12)$ \\
\hline Monocytes & $0.4(0.1)$ & $0.7(0.2)$ & $0.3(0.2)$ & $2.0(0.8)$ \\
\hline Neutrophils & $0.9(0.6)$ & $4.4(2.0)$ & $0.5(0.3)$ & $0.8(0.3)$ \\
\hline Lymphocytes & $2.8(1.1)$ & $3.5(1.3)$ & $2.0(0.2)$ & $1.0(0.3)$ \\
\hline
\end{tabular}

increased amounts of high molecular weight proteins were found in subjects exposed to asbestos, indicate that such a strategy might be less informative.

\section{EVALUATION OF 2-DE PATTERNS}

Separated proteins were detected using highly sensitive silver staining with a detection limit of 1-5 ng/spot. ${ }^{17}{ }^{18}$ The protein patterns in the gels were then analysed as digitised images using a coupled charged device (CCD) camera $(1024 \times 1024$ pixels $)$ in combination with a computerised imaging eight-bit system designed for evaluations of 2-DE patterns (Visage 4.6, Millipore Biolmage, Ann Arbor, Michigan, USA). The amount of protein in a spot was assessed as background corrected optical density, integrated over all pixels in the protein spot, and expressed as integrated optical density (IOD). In order to correct for differences in total silver stain intensity between different 2-DE images, quantification ratios were calculated. This was performed by using matching protein spots in the 2-DE images and then calculating the central tendency of distribution of the log ratios of the IOD for the matched spots. ${ }^{11}$

Following detection and quantification of proteins, 2-DE images from different individuals were compared and the same proteins

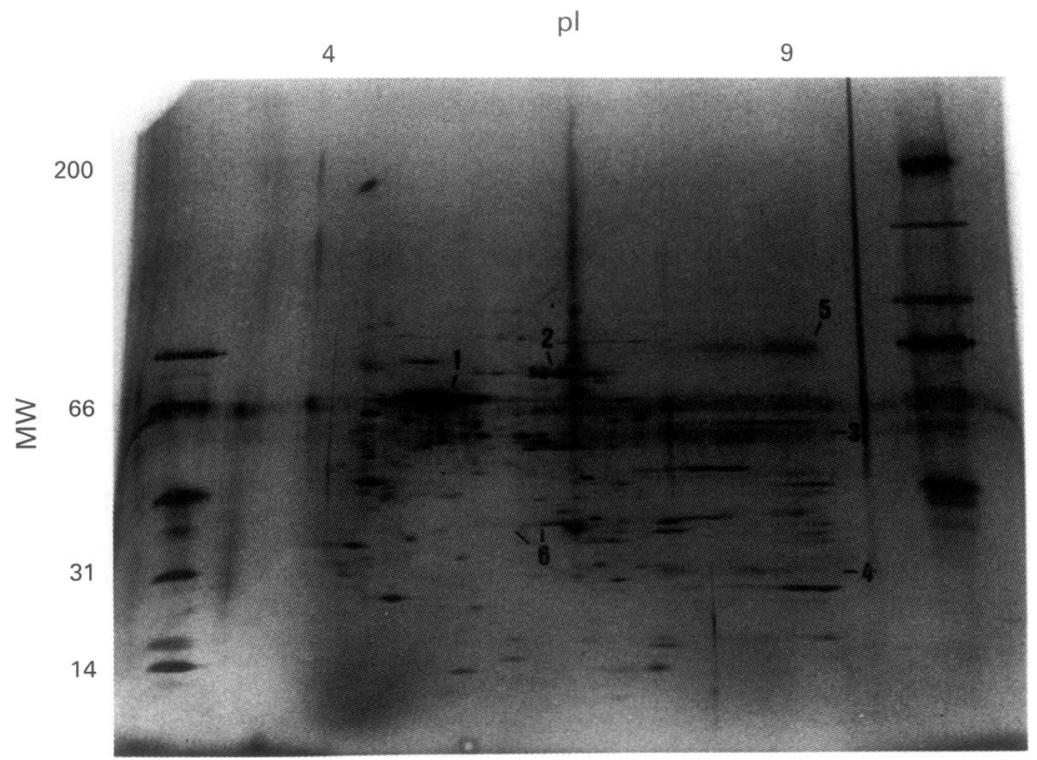

Figure 1 Two dimensional protein pattern of bronchoalveolar lavage fluid. Proteins were separated by isoelectrical focusing followed by SDS-polyacrylamide gel electrophoresis and detected by silver staining. Proteins were identified by reference proteins and by Western blotting: 1, albumin; 2, transferrin; 3, immunoglobulin heavy chains; 4, immunoglobulin light chains; 5, plasminogen; 6, lipocortin-1. appearing in different $\mathrm{BAL}$ fluids were matched. About 10 protein spots, which appeared in all individuals, were manually selected; the software then corrected for spatial differences between different images and made geometrical transformations of the images. It was thus possible to make an automated gel matching of the different 2-DE patterns. Protein spots appearing in more than one individual were automatically given a pattern number and saved in a BAL fluid data base. This data base was used to evaluate qualitative and quantitative differences in BAL fluid 2-DE patterns between individuals or groups of individuals. Only changes in IODs by a factor of more than 3 were regarded as valid. Proteins were identified by using reference proteins or by Western blotting. ${ }^{15}$ The antibodies against lipocortin-1 were provided by Dr Jefferey L Browning, Biogen Inc, Cambridge, Massachusetts, USA. ${ }^{19}$

\section{STATISTICAL ANALYSIS}

Values are given as mean and standard error of the mean (SE). Significances of qualitative differences in protein appearances were calculated using Fisher's exact test or Wilcoxon's rank sum test. Significances of quantitative differences in protein intensities and the total number of cells were calculated using the twotailed Student's $t$ test, and significances of differences in protein patterns were calculated using non-parametric multivariate variance analysis (ANOVA).

\section{Results}

CELL COUNTING

The total number of blood cells in BAL fluid samples from the different subjects is given in table 1. The lowest number was found in nonsmoking controls while the highest number was found in smoking subjects exposed to asbestos. On a group basis, the total cell number was significantly higher both in non-smoking and in smoking subjects exposed to asbestos than in non-smoking controls ( $p$ $<0.05$ in both cases). Compared with smoking controls, however, the cell numbers in subjects exposed to asbestos were not significantly increased ( $p>0.05$ for both smokers and nonsmokers).

Table 1 also shows the results of the differential cell counting. In all subjects the dominant cells were macrophages (> 90\%). In smokers, but not in non-smokers, a relatively large number of pigmented macrophages ( 54 (11)\%) containing black grains were found. Otherwise there were no significant differences in differential cell counts between smokers and non-smokers, although some of the smokers showed increased numbers of neutrophils and lymphocytes. The asbestos exposed group showed no significant differences in the differential cell count compared with controls (table 1).

PROTEIN PATTERNS OF BAL FLUID

About 200 protein spots were detected in each 2-DE pattern. Most of the proteins had a molecular weight of $30-70 \mathrm{kDa}$ and a pI 

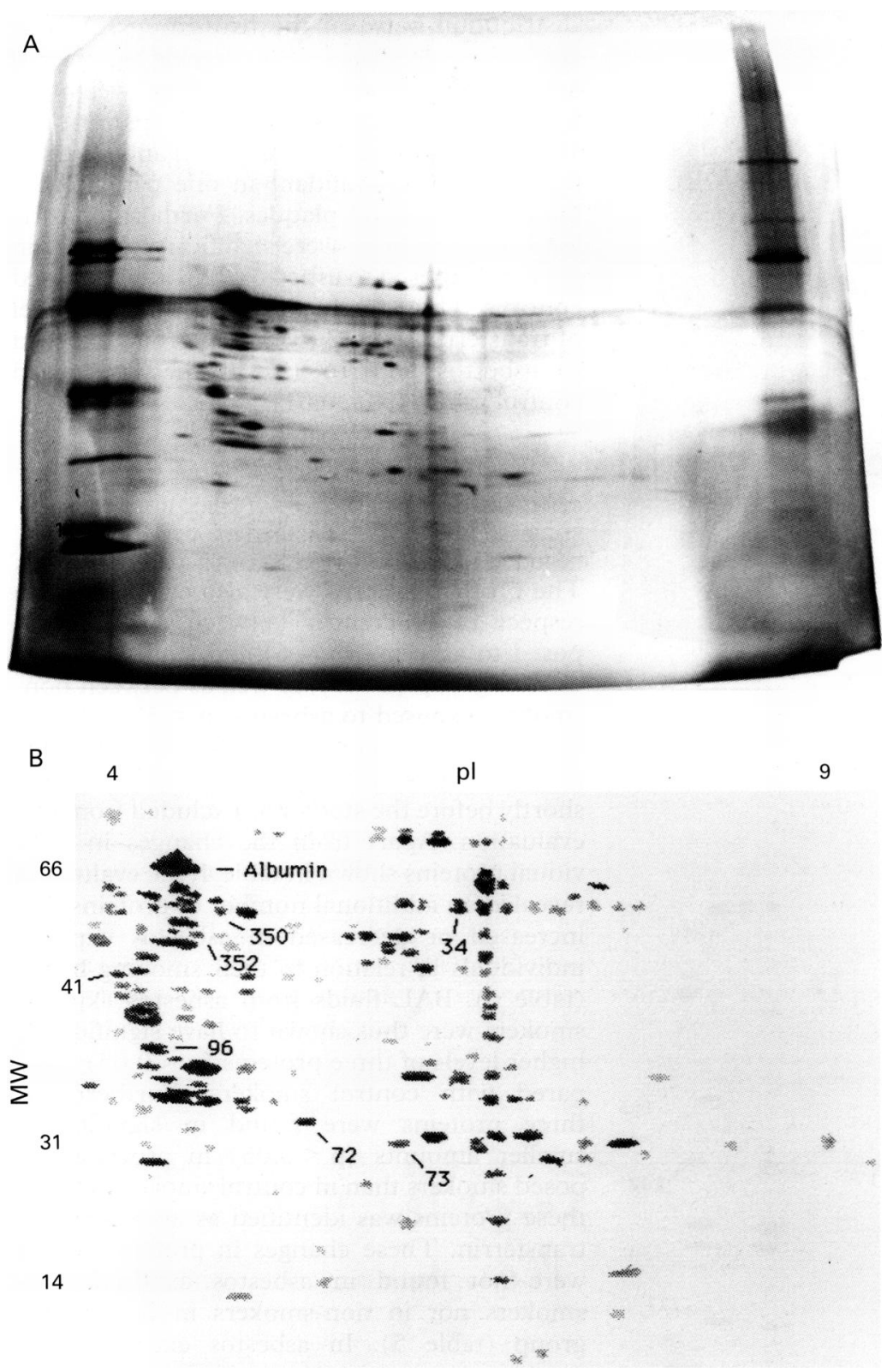

Figure 2 (A) Silver stained and (B) computer derived two dimensional protein patterns of bronchoalveolar lavage fluids from healthy non-smokers. Protein spots indicated by pattern numbers in $B$ were significantly $(p<0.05)$ decreased in smokers compared with non-smokers. The figures are images of one representative individual; additional information on the protein spots indicated with pattern numbers is given in table 3.

between 4.5 and 7.0 (fig 1 ). In the control group the total protein concentration was slightly higher in smokers (490 (140) $\mathrm{mg} / \mathrm{l})$ than in non-smokers $(250(30) \mathrm{mg} / \mathrm{l})$, but the differences were not significant. By contrast, a significantly higher number of proteins $(\mathrm{p}<0.05)$ was detected in smokers $(230(10))$ than in non-smokers (150 (10)). As in human blood plasma, large amounts of albumin, transferrin and immunoglobulins were identified in the 2-DE BAL fluid pattern. Furthermore, BAL fluid was shown to contain two major isoforms of lipocortin-1, each with a molecular mass of $38 \mathrm{kDa}$ and with isoelectrical points of 5.8 and 6.5 , respectively (fig 1 ). This anti-inflammatory protein has previously been shown to be induced by airway corticosteroid treatment and its degradation may be of importance in various lung diseases. ${ }^{2021}$ In the present study the levels of lipocortin were not significantly changed in smokers or in subjects
Table 2 Mean (SE) differences in the number of basic and high molecular weight proteins in $B A L$ fluid from subjects exposed to asbestos and healthy controls. The values show the distribution (\%) of protein spots with a pI of $>7.5$ or a $M W$ of $\geqslant 85 \mathrm{kDa}$ in $2-D E$ patterns from controls (non-smokers $(n=9)$ and smokers $(n=9)$ ) and from subjects exposed to asbestos (non-smokers $(n=5)$ and smokers $(n=6))$

\begin{tabular}{lll}
\hline & Distribution (\%) \\
\cline { 2 - 3 } & $p I>7.5$ & $M W \geqslant 85 k D a$ \\
\hline Controls & $4(1)$ & $3(2)$ \\
$\quad$ Non-smokers & $16(4)^{\star \star}$ & $6(1)$ \\
Smokers & & \\
Asbestos exposed & $12(2)^{\star \star}$ & $21(5)^{\star \star}$ \\
$\quad$ Non-smokers & $15(3)^{\star \star}$ & $16(2)^{\star \star}$ \\
\hline Smokers & & \\
\hline
\end{tabular}

$\star \star \mathrm{p}<0.01$ versus non-smoking controls.

exposed to asbestos, and BAL fluid samples from all individuals were shown to contain relatively large amounts of either one or both isoforms.

COMPARISON OF PROTEIN PATTERNS BETWEEN NON-SMOKERS AND SMOKERS

Evaluation of the protein patterns showed an apparent shift towards increased levels of basic proteins in smokers compared with nonsmokers. This is illustrated in figs 2 and 3 with examples of silver stained 2-DE gels (figs $2 \mathrm{~A}$ and $3 \mathrm{~A}$ ), as well as with the computer-derived 2-DE patterns from the same samples (figures $2 \mathrm{~B}$ and $3 \mathrm{~B})$. Calculating the overall distribution of the number of basic proteins showed a fourfold increase $(p<0.01)$ of proteins with pI $>7.5$ in smokers compared with nonsmokers (table 2). As shown in table 3, several changes in individual protein levels were found and variance analysis (ANOVA) demonstrated a significant difference in the patterns between smokers and non-smokers $(\mathrm{p}<0.05)$. Twelve individual proteins were increased in smokers compared with non-smokers and, of these, seven had a pI of $>7.5$ (table 3, fig 3). Eight of the proteins were more common in smokers than in non-smokers - that is, they appeared in five or more of the nine smokers but in none or only one of the nine non-smokers ( $p<0.05$ ), and four of the protein spots were increased by a factor of more than 3 . Three of these were identified as isoforms of immunoglobulins that were expressed as several large clusters of spots (table 3, fig 1).

Evaluation of the protein patterns also revealed significantly $(\mathrm{p}<0.05)$ lower levels of eight proteins in BAL fluid from smokers compared with non-smokers (table 3, fig 2). Among these proteins was albumin. One of the proteins (pattern no. 350) appeared in five out of nine non-smokers but was not present in any BAL fluid from smokers. Six protein spots were increased by a factor of more than 3 in non-smokers compared with smokers (fig 2).

COMPARISON OF PROTEIN PATTERNS BETWEEN ASBESTOS EXPOSED SUBJECTS AND UNEXPOSED CONTROLS

The total protein concentration in BAL fluid was not increased in the patients exposed to asbestos ( $n=12)$ compared with unexposed controls ( $\mathrm{n}=18$, ) but the BAL fluid protein 

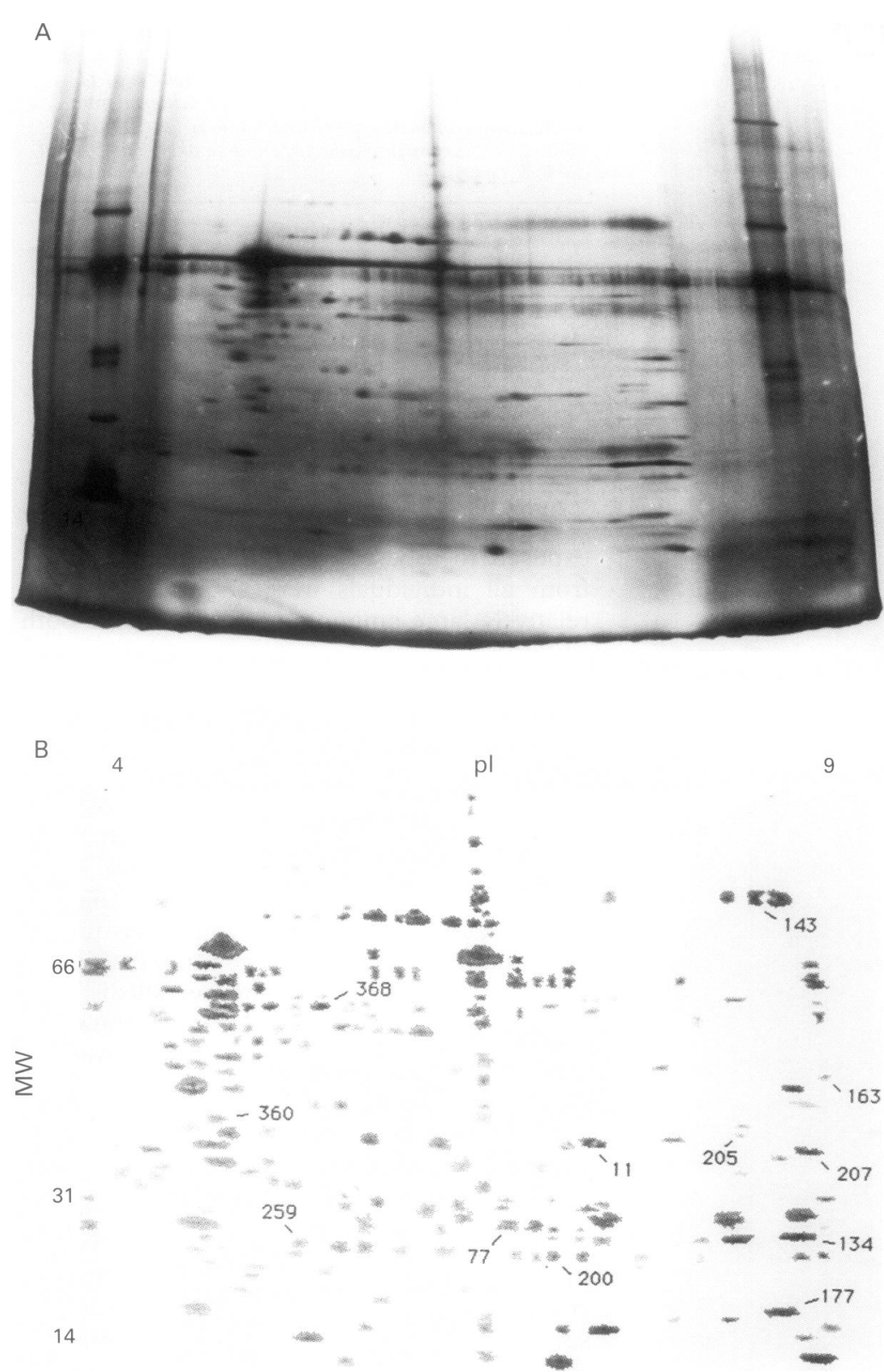

Figure 3 (A) Silver stained and (B) computer derived two dimensional protein patterns of bronchoalveolar lavage fluid from smokers. Spots indicated by pattern numbers in $B$ were significantly $(p<0.05)$ increased in smokers compared with non-smokers. The figures are images of one representative individual; additional information on the protein spots indicated with pattern numbers is given in table 3.

patterns from the asbestos exposed group contained several high molecular weight proteins (fig 4). Calculating the overall distribution of high molecular weight proteins showed an approximately fivefold increase $(p<0.01)$ in proteins with a molecular weight of $\geqslant 85 \mathrm{kDa}$ in subjects exposed to asbestos compared with controls (table 2). Evaluation of the protein patterns discriminated 13 individual protein spots that were increased in asbestos exposed subjects compared with controls (table 4, fig 4). Six of these 13 proteins had a molecular weight of $\geqslant 85 \mathrm{kDa}$ (fig 4 ). The proteins were clearly demonstrable in five or more of the 12 individuals exposed to asbestos but were not detected in any or in only one of 18 controls ( $p$ $<0.05$ ). Using analysis of variance (ANOVA) a highly significant difference in the patterns between asbestos exposed subjects and controls was found $(p<0.002)$. These changes were not related to the differences in the sex distribution between the two groups. Among the high molecular weight proteins a cluster of acidic proteins with a molecular weight of $150-165 \mathrm{kDa}$ and a pI of 5.5 (pattern no. 1544,1545 , and 1592) was noted and found to be particularly abundant in one patient with progressive pleural plaques. Furthermore, the levels of transferrin were significantly higher in subjects exposed to asbestos than in unexposed controls. Thus, the mean (SE) total IOD level of transferrin was 32 (5) in the group exposed to asbestos and 16 (3) in the unexposed control group $(\mathrm{p}<0.01)$.

COMPARISON OF PROTEIN PATTERN BETWEEN SUBJECTS EXPOSED TO ASBESTOS AND CONTROLS IN RELATION TO SMOKING HABITS AND DIAGNOSIS The protein patterns were also evaluated with respect to differences between smokers exposed to asbestos $(n=6)$ and smokers in the control group ( $n=9$ ), as well as between nonsmokers exposed to asbestos $(n=5)$ and nonsmokers in the control group $(n=9)$. One asbestos exposed individual who quit smoking shortly before the study was excluded from this evaluation. Apart from the changes in individual proteins shown in table 4 , the evaluation revealed an additional number of proteins that increased or decreased in asbestos exposed individuals in relation to their smoking habits (table 5). BAL fluids from asbestos exposed smokers were thus shown to have significantly higher levels of three proteins $(p<0.05)$ compared with control smokers. Furthermore, three proteins were found in significantly smaller amounts $(p<0.05)$ in asbestos exposed smokers than in control smokers. One of these proteins was identified as an isoform of transferrin. These changes in protein pattern were not found in asbestos exposed nonsmokers nor in non-smokers in the control group (table 5). In asbestos exposed nonsmokers, but not in asbestos exposed smokers or control smokers, one protein was found to be increased and two proteins decreased compared with control non-smokers $(p<0.05)$. Calculating the distribution of basic proteins it was found that both asbestos exposed smokers and asbestos exposed non-smokers showed an approximately threefold increase $(p<0.01)$ in proteins with a pI of $>7.5$ compared with control non-smokers (table 2). Furthermore, as shown in table 5 , one protein was found to be decreased in smokers and in asbestos exposed non-smokers compared with nonsmoking controls $(p<0.01)$.

One protein spot (no. 1471 in table 6) was found only in four individuals with asbestos pleuritis but was not detected in BAL fluid from 18 unexposed subjects or from five patients with pleural plaque, except for one patient with progressive disease. The level of another protein spot (no. 1570 in table 6) was found to be significantly increased in patients with pleural plaque compared with patients with pleuritis and healthy controls $(\mathrm{p}<0.01)$. Furthermore, one protein spot (no. 1555 in table 6) was found only in the two patients who developed a progressive pleural disease. 
Table 3 Proteins found in increased (I-XII) or decreased (XIII-XX) amounts in BAL fluid from smokers $(n=9)$ and non-smokers $(n=9)$. Proteins I-VIII appeared in 5-9 smokers but not in any or in only one non-smoker. Proteins IX-XII were increased by a factor of three or more in smokers. Protein XIII appeared in five non-smokers but not in any smoker, and proteins $X I V-X X$ were decreased by a factor of three or more in smokers

\begin{tabular}{|c|c|c|c|c|}
\hline \multirow[b]{2}{*}{ Protein } & \multirow[b]{2}{*}{$M W(k D a)$} & \multirow[b]{2}{*}{$p I$} & \multicolumn{2}{|l|}{$I O D$} \\
\hline & & & Non-smokers & Smokers \\
\hline \multicolumn{5}{|l|}{ Increased } \\
\hline I (77 / Ig light chain) & 24 & 7.1 & 0.3 & $1.1(0.4)$ \\
\hline II $(143 /$ IgG $)$ & 92 & 8.8 & $<0.1$ & $2.2(0.6)$ \\
\hline III $(163)$ & 45 & 9.3 & 0.5 & $1.7(0.6)$ \\
\hline IV (177) & 16 & 8.9 & 0.4 & $1.3(0.6)$ \\
\hline $\mathrm{V}(200)$ & 22 & 7.4 & 0.3 & $1.0(0.7)$ \\
\hline VI (205) & 35 & 8.6 & $<0.1$ & $1.0(0.3)$ \\
\hline VII (207) & 33 & 9.1 & 0.6 & $2.1(0.6)$ \\
\hline VIII (259) & 22 & 6.1 & $<0.1$ & $1.6(0.6)$ \\
\hline IX (11) & 34 & 7.6 & $1.0(0.2)$ & $3.6(1.1)$ \\
\hline $\mathrm{X}$ (134 / Ig light chain) & 27 & 9.0 & $0.4(0.2)$ & $3.0(0.9)$ \\
\hline $\mathrm{XI}(360)$ & 38 & 5.4 & $0.2(0.2)$ & $1.3(0.3)$ \\
\hline XII (368) & 56 & 6.2 & $0.4(0.2)$ & $3.2(0.7)$ \\
\hline \multicolumn{5}{|l|}{ Decreased } \\
\hline XIII (350) & 59 & 5.0 & $1.6(0.2)$ & $<0.1$ \\
\hline XIV (albumin) & 68 & 5.5 & $137 \quad(34)$ & $56(6)$ \\
\hline XV (34) & 60 & 6.3 & $3.7(0.9)$ & $1.0(0.5)$ \\
\hline XVI (41) & 50 & 4.4 & $4.6(1.6)$ & $0.7(0.2)$ \\
\hline XVII (72) & 31 & 5.6 & $1.9(0.4)$ & $0.4(0.2)$ \\
\hline XVIII (73) & 29 & 6.1 & $1.9(0.5)$ & $0.5(0.2)$ \\
\hline XIX (96) & 40 & 4.6 & $3.2(1.1)$ & $0.1(0.1)$ \\
\hline $\mathrm{XX}(352)$ & 55 & 4.8 & $1.1(0.4)$ & $0.1(0.1)$ \\
\hline
\end{tabular}

IOD $=$ integrated optical density (mean(SE)).

Numbers and names in parentheses are the pattern numbers and protein names used in the computer database (fig 2 ). The amounts of protein were all significantly different in smokers compared with non-smokers $(\mathrm{p}<0.05)$.

\section{Discussion}

This study indicates that two dimensional gel electrophoresis of BAL fluid may be used to detect changes in airway protein expression caused by smoking and/or exposure to asbestos. In the control group smokers displayed higher levels of basic proteins than nonsmokers. Interestingly, in subjects exposed to asbestos both non-smokers and smokers ap-

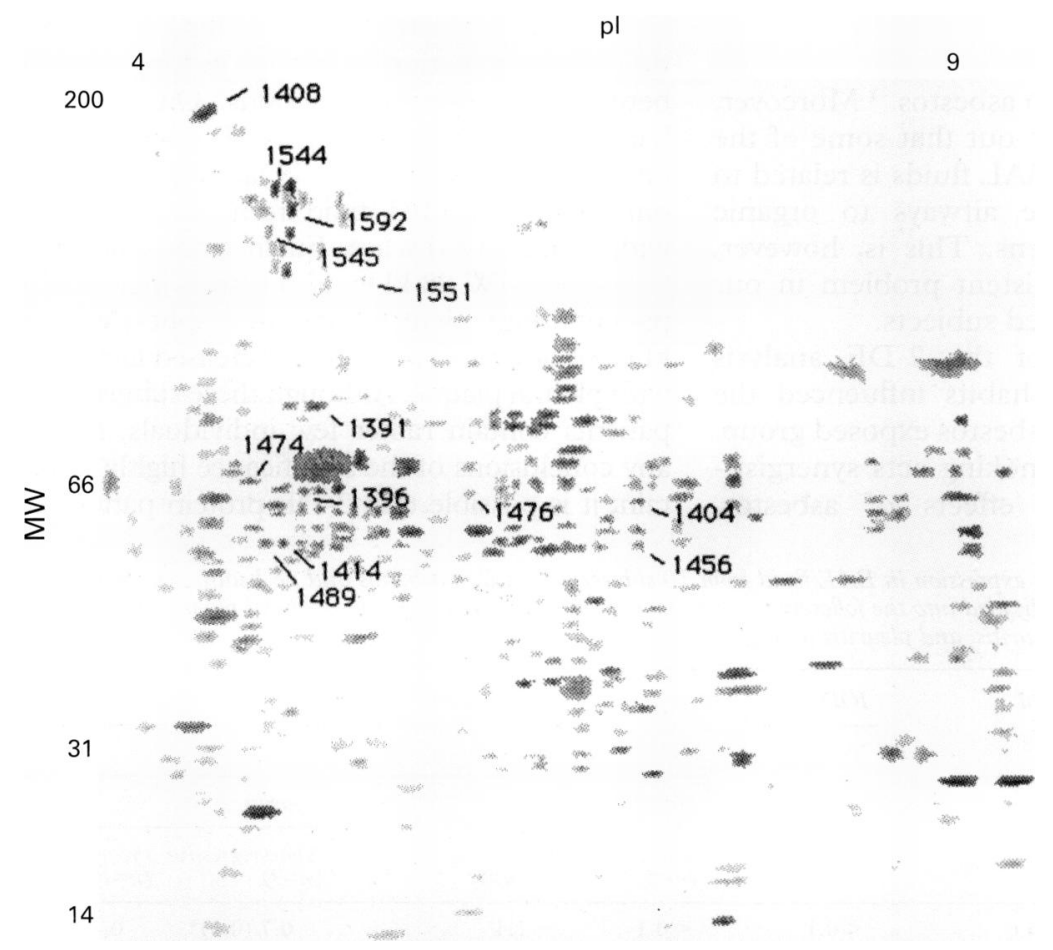

Figure 4 Computer derived two dimensional protein pattern of bronchoalveolar lavage fluid from subjects exposed to asbestos. Protein spots indicated by pattern numbers were significantly $(p<0.05)$ increased in the asbestos-exposed group compared with controls. The figure (illustrating the positions of the proteins at issue) is a composite image of two representative individuals; additional information on the protein spots indicated with pattern numbers is given in table 4.
Table 4 Proteins found in increased amounts in $B A L$ fluid from 12 subjects exposed to asbestos and 18 controls. The proteins appeared in five or more asbestos exposed individuals but not in any or in only one of the controls $(p<0.05)$

\begin{tabular}{lcccl}
\hline & \multicolumn{3}{c}{ IOD } \\
\cline { 3 - 5 } Protein & $\begin{array}{c}M W \\
(k D a)\end{array}$ & $p I$ & Unexposed & $\begin{array}{l}\text { Asbestos } \\
\text { exposed }\end{array}$ \\
\hline I (1391) & 85 & 4.8 & $<0.1$ & $1.5(0.4)$ \\
II (1396) & 63 & 4.8 & $<0.1$ & $2.3(0.8)$ \\
III (1404) & 60 & 6.5 & 0.2 & $1.2(0.5)$ \\
IV (1408) & 186 & 4.4 & $<0.1$ & $5.4(3.1)$ \\
V (1414) & 56 & 4.8 & $<0.1$ & $1.0(0.4)$ \\
VI (1456) & 55 & 6.5 & $<0.1$ & $1.0(0.2)$ \\
VII (1474) & 65 & 4.6 & $<0.1$ & $1.7(0.5)$ \\
VIII (1476) & 62 & 5.6 & $<0.1$ & $1.5(0.4)$ \\
IX (1489) & 56 & 4.6 & $<0.1$ & $1.9(0.4)$ \\
X (1544) & 165 & 5.5 & $<0.1$ & $3.4(1.9)$ \\
XI (1545) & 147 & 5.5 & $<0.1$ & $2.0(1.2)$ \\
XII (1551) & 134 & 6.0 & $<0.1$ & $2.1(1.4)$ \\
XIII (1592) & 157 & 5.5 & $<0.1$ & $2.1(0.9)$ \\
& & & &
\end{tabular}

IOD = integrated optical density (mean (SE)). Numbers in parentheses are the pattern numbers used in the computer database (fig 3).

peared to have an increased number of basic proteins. Many proinflammatory proteins are highly basic, suggesting that the BAL fluid protein pattern in smokers and asbestos exposed subjects reflects, at least partially, airway inflammation. Among the increased proteins in smokers there were different forms of IgG. In 2-DE immunoglobulins are expressed as several spots of the light and heavy chains with a pI between 5 and 9 , and increased amounts of IgG have previously been recognised in BAL fluid from smokers. ${ }^{22}$ A number of proteins were also found to be decreased in smokers compared with non-smokers, one of which was identified as albumin. The reason for this is unclear, but lower levels of albumin in BAL fluid from smokers have previously been described and albumin is regarded as a negative acute phase protein. ${ }^{23}$

When studying the 2-DE patterns of individuals exposed to asbestos we first made comparisons between all individuals in the unexposed group and all subjects in the asbestos exposed group. We then found that BAL fluids from asbestos exposed subjects contained clearly increased amounts of high molecular weight proteins with sizes ranging from 85 to $186 \mathrm{kDa}$. Interestingly, in one patient with progressive pleural plaques these high molecular weight proteins were particularly abundant, while they were not detected at all - or only in very small amounts - in the control group. Although these changes did not correlate with age or smoking habits, we cannot exclude the possibility that the differences in age, on the whole, between the two groups may have had some impact on the findings. Human plasma contains several high molecular weight proteins and increased amounts of large proteins in BAL fluid may therefore reflect an extravasation of plasma into the airways caused by an asbestos-related inflammation. Exposure to asbestos is known to stimulate the production of inflammatory mediators that can increase the permeability in the pulmonary vessels. ${ }^{24-26}$ Accumulation of protein-rich fluid in the airways has also been suggested as a significant 
Table 5 Differences in protein patterns in the BAL fluid of asbestos exposed subjects in relation to their smoking habits. The amounts of proteins I-VI were significantly increased or decreased in asbestos exposed smokers $(n=6)$ but not in control non-smokers $(n=9)$ or asbestos exposed non-smokers $(n=5)$ compared with control smokers $(n=9)$. Proteins

VII-IX were significantly increased or decreased in asbestos exposed non-smokers but not in asbestos exposed smokers or control smokers compared with control non-smokers. Protein $X$ was significantly decreased in control smokers, asbestos exposed smokers, and asbestos exposed non-smokers compared with control non-smokers.

\begin{tabular}{|c|c|c|c|c|c|c|}
\hline \multirow[b]{3}{*}{ Protein } & \multirow{3}{*}{$\begin{array}{l}M W \\
(k D a)\end{array}$} & \multirow[b]{3}{*}{$p I$} & \multicolumn{4}{|l|}{$I O D$} \\
\hline & & & \multicolumn{2}{|l|}{ Controls } & \multicolumn{2}{|l|}{ Asbestos-exposed } \\
\hline & & & Non-smokers & Smokers & Non-smokers & Smokers \\
\hline I (1407) & 40 & 6.6 & $<0.1$ & $<0.1$ & $<0.1$ & $2.9(1.0)^{\star}$ \\
\hline II (1588) & 70 & 4.9 & $<0.1$ & $<0.1$ & $0.4(0.4)$ & $3.7(2.1)^{\star}$ \\
\hline III (61) & 36 & 4.4 & $0.6(0.2)$ & $1.0(0.5)$ & $0.9(0.6)$ & $3.6(0.8)^{\star}$ \\
\hline IV (transferrin) & 78 & 5.7 & $2.8(0.6)$ & $4.0(1.0)$ & $4.5(1.1)$ & $0.8(0.3)^{\star}$ \\
\hline V (25) & 54 & 5.4 & $5.7(2.0)$ & $6.9(1.9)$ & $2.1(0.6)$ & $1.3(0.4)^{\star}$ \\
\hline VI (106) & 66 & 6.1 & $8.4(1.1)$ & $11.8(2.8)$ & $3.6(1.6)$ & $2.4(0.5)^{\star}$ \\
\hline VII (1388) & 60 & 6.7 & $<0.1$ & $0.4(0.3)$ & $3.8(1.6)^{\star}$ & $1.2(0.2)$ \\
\hline VIII (5) & 27 & 4.6 & $3.4(0.8)$ & $4.0(1.6)$ & $0.7(0.3)^{\star}$ & $8.6(2.5)$ \\
\hline IX (98) & 13 & 5.1 & $1.6(0.4)$ & $1.7(0.9)$ & $0.1(0.1)^{\star}$ & $1.3(0.8)$ \\
\hline$X(72)$ & 34 & 5.0 & $1.9(0.4)$ & $0.4(0.2)^{\star \star}$ & $0.2(0.1)^{\star \star}$ & $0.2(0.1)^{\star \star}$ \\
\hline
\end{tabular}

IOD = integrated optical density (mean (SE)).

Numbers and names in parentheses are the pattern numbers and protein names used in the computer database.

${ }^{\star} \mathrm{p}<0.05 ;{ }^{\star \star} \mathrm{p}<0.01$ although the mechanisms for this are not fully understood. It is possible, thus, that the proteins detected in this study may prove to be important in that respect. One of the proteins found to be decreased in asbestos exposed smokers was identified as an isoform of transferrin. With 2-DE, transferrin can be separated into different isoforms with slightly different isoelectrical points (around pI 6) and also with small differences in molecular weight $(78-80 \mathrm{kDa})$, at least in part, depending on differences in glycosylation or iron content. ${ }^{28}$ To our knowledge, the importance of different forms of transferrin has not been demonstrated, and the relevance of this specific isoform of transferrin is therefore unclear. The acidic pI (5.7) of the isoform, however, indicates that it is an iron-containing form of transferrin. ${ }^{28}$ In contrast to this isoform, the overall IOD of total transferrin appeared to be higher in asbestos exposed subjects than in controls. This illustrates the advantage of a high resolution technique such as $2-\mathrm{DE}$ compared with total protein determinations.

Among the 12 subjects exposed to asbestos five had radiographic signs of pleural plaques alone while seven were diagnosed as pleuritis. Ten of the patients were re-examined after four years; one of the patients with pleuritis and one of the patients with pleural plaque then showed radiographic signs of progression while the others appeared to have non-progressive disease. Previously it has been shown that serial changes in lung function in subjects exposed to asbestos are not closely related to the level of prior exposure or smoking habits. Rather, loss of diffusion capacity was associated with the number of neutrophils in BAL fluid. ${ }^{29}$ In the present study, however, we could not find any correlation between inflammatory cells and lung function in the first examination or change in lung function between the two examinations. On the other hand, a comparison of the 2-DE maps revealed one protein spot (MW $64 \mathrm{kDa}, \mathrm{pI} 6.3$ ) that was only detected in BAL fluid from the two patients with progessive disease. Furthermore, one protein spot (MW $88 \mathrm{kDa}, \mathrm{pI} 5.6$ ) was increased in patients with pleuritis and one spot (MW 48 $\mathrm{kDa}, \mathrm{pI} 5.0$ ) was specifically increased in patients with pleural plaque. Although these subgroups of patients contain rather few individuals, making any conclusions of the significance highly uncertain, it is possible that 2-DE protein patterns of

It is well known that smoking acts synergistically on the adverse effects of asbestos,

Table 6 Differences in protein expression in BAL fluid from 10 subjects exposed to asbestos and 18 healthy controls. The asbestos exposed subjects were divided into the following groups: non-progressive pleural plaque, pleural plaque with progression, non-progressive pleuritis, and pleuritis with progression.

\begin{tabular}{|c|c|c|c|c|c|c|c|}
\hline \multirow[t]{4}{*}{ Protein } & \multirow[t]{4}{*}{$M W(k D a)$} & \multirow[t]{4}{*}{$p I$} & \multicolumn{5}{|l|}{$I O D$} \\
\hline & & & \multirow[t]{3}{*}{ Unexposed } & \multicolumn{4}{|l|}{ Asbestos exposed } \\
\hline & & & & \multicolumn{2}{|l|}{ Pleural plaque } & \multicolumn{2}{|l|}{ Pleuritis } \\
\hline & & & & $\begin{array}{l}\text { Non-progressive } \\
(n=5)\end{array}$ & $\begin{array}{l}\text { Progressive } \\
(n=1)\end{array}$ & $\begin{array}{l}\text { Non-progressive } \\
(n=3)\end{array}$ & $\begin{array}{l}\text { Progressive } \\
(n=1)\end{array}$ \\
\hline I (1471) & 88 & 5.6 & $<0.1$ & $<0.1$ & 1.4 & $0.7(0.4)^{\star}$ & 0.4 \\
\hline II (1570) & 48 & 5.0 & $<0.1$ & $0.6(0.2)^{\star \star}$ & 0.3 & $0.1(0.1)$ & $<0.1$ \\
\hline III (1555) & 64 & 6.3 & $<0.1$ & $<0.1$ & 1.1 & $<0.1$ & 11.4 \\
\hline
\end{tabular}

IOD = integrated optical density (mean (SE)).

Numbers in parentheses are pattern numbers used in the database.

${ }^{\star} p<0.05$ versus non-progressive pleural plaque; ${ }^{\star \star} p<0.01$ versus non-progressive pleuritis. 
BAL fluid could become an important instrument to aid both diagnostic and prognostic determinations in subjects exposed to asbestos.

In summary, the present study demonstrates that 2-DE of BAL fluid may be useful for detection of changes in airway protein expression caused by smoking and/or asbestos exposure. Although many of the proteins remain to be identified, it can be anticipated that characterisation of changes in the 2-DE pattern may be one way of understanding important mechanisms in the pathogenesis of diseases associated with these exposures. Recent techniques, such as immunoblotting, microsequencing, and recombinant protein expression systems, have improved the possibility to link 2-DE results with the human genome. ${ }^{30}$ Similar to gene data bases, 2-DE protein data bases are now being constructed and will certainly be an important instrument for further characterisation of the 2-DE patterns in BAL fluid.

The authors gratefully acknowledge the technical assistance of Susanne Bornemo and the statistical expertise of Asa Gustafsson and would also like to thank Dr Jefferey L Browning, Biogen Inc, Cambridge, Massachusetts, USA for kindly providing the lipocortin antibodies. This work was supported by the Swedish Work Environment Fund.

1 Robinson DS, Bentley AM, Hartnell A, Kay AB, Durham SR. Activated memory $T$ helper cells in bronchoalveolar lavage fluid from patients with atopic asthma: relation to asthma symptoms, lung function, and bronchial responasthma symptoms, lung function,

2 Bjermer L, Eklund A, Blaschke E. Bronchoalveolar lavage fibronectin in patients with sarcoidosis: correlation to hyaluronan and disease activity. Eur Respir $\mathcal{F}$ 1991;4:965 71.

3 Sörensen J, Kald B, Tagesson C, Lindahl M. Plateletactivating factor and phospholipase $A_{2}$ in patients with septic shock and trauma. Intensive Care Med 1994;20:55561 .

4 Turner-Warwick ME, Haslam PL. Clinical applications of bronchoalveolar lavage: an interim view. $\mathrm{Br} f$ Chest 1986;80:105-21.

5 Henderson RF. Use of bronchoalveolar lavage to detect lung damage. In: Gardner DE, Crapo JD, Massaro EJ, eds.
Toxicology of the lung. New York: Raven Press, 1988:23968 .

6 Barbers RG, Abraham JL. Asbestosis occurring after brief inhalational exposure: usefulness of bronchoalveolar lav age in diagnosis. $\mathrm{Br} \mathcal{F}$ Ind $\mathrm{Med}$ 1989;46:106-10.

7 O'Farrell PH. High resolution two dimensional gel electrophoresis of proteins. $\mathcal{F}$ Biol Chem 1975;250:4007-21.

8 Anderson L, Anderson N. Some perspectives on twodimensional protein mapping. Clin Chem 1984;30:1898905.

9 Dunn MJ. Two-dimensional gel electrophoresis of proteins. f Chromatogr 1987;418:145-85.

10 Hader D-P, Kauer G. Image analysis techniques for automatic evaluation of two-dimensional electrophoresis. Electrophoresis 1990;11:407-15.
11 Lindahl $M$, Stahlbom B, Tagesson C. Two-dimensional gel electrophoresis of nasal and bronchoalveolar lavage fluids after occupational exposures. Electrophoresis 1995 16:1199-204.

12 Lenz A-G, Meyer B, Costabel U, Maier K. Bronchoalveolar lavage fluid proteins in human lung disease: analysis by two-dimensional electrophoresis. Electrophoresis 1993; 14:242-4.

13 Bradford $M$. A rapid and sensitive method for the quantification of microgram quantities of protein utilising the principle of protein-dye binding. Anal Biochem 1976; 72:248-52.

14 Celis JE, Bravo R. Two-dimensional gel electrophoresis of proteins. Orlando:Academic Press, 1984.

15 Lindahl $M$, von Schenck $H$, Tagesson C. Isolation and characterisation of phospholipase $\mathrm{A}_{2}$ from rat lung with affinity chromatography and two-dimensional gel electrophoresis. Biochim Biophys Acta 1989;1005:282-8.

16 Laemmli UK. Cleavage of structural proteins during the assembly of the head of bacteriophage T4. Nature 1970;227:680-5.

17 Switzer RC III, Merril CR, Shifrin SA. A highly sensitive silver stain for detecting proteins and peptides in polyacrylamide gels. Anal Biochem 1979;98:231-7.

18 Oakley BR, Kirsch DR, Morris NR. A simplified ultrasensitive silver stain for detecting proteins in polyacrylamide gels. Anal Biochem 1980;105:361-3.

19 Pepinsky RB, Sinclair LK, Dougas I, Liang C-M, Lawton P, Browning JE. Monoclonal antibodies to lipocortin-1 as probes for biological function. FEBS Lett 1990;261:24752 .

20 Ambrose MP, Hunninghake GW. Corticosteroids increase lipocortin 1 in BAL fluid from normal individuals and patients with lung disease. F Appl Physiol 1990;68:1668patien.

21 Smith SF, Tetley TD, Guz A, Flower RJ. Detection of lipocortin 1 in human lung lavage fluid: lipocortin degradation as a possible proteolytic mechanism in the control of inflammatory mediators and inflammation Environ Health Perspect 1990;85:135-44.

22 Bell DY, Haseman JA, Spock A, McLennan G, Hook GER Plasma proteins of the bronchoalveolar surface of the lungs of smokers and nonsmokers. Am Rev Respir Dis 1981;124:72-8.

23 Burke WMJ, Roberts CM, Bryant DH, Cairns D, Yeates $M$ Morgan GW, et al. Smoking-induced changes in epithelial lining fluid volume cell density and protein. Eur Respir 7 1992;5:780-4.

24 Ljungman AG, Lindahl M, Tagesson C. Asbestos fibres and man made mineral fibres: induction release of tumour necrosis factor- $\alpha$ from rat alveolar macrophages. Occup necrosis factor- $\alpha$ from rat al
Environ Med 1994;51:777-83.

25 Schwartz DA, Galvin JR, Frees KL, Dayton CS, Burmeister LF, Merchant JA, et al. Clinical relevance of cellular mediators of inflammation in workers exposed to asbestos. Am Rev Respir Dis 1993;148:68-74.

26 Lindahl M, Hede AR, Tagesson C. Lysophosphatidylcholine increases airway and capillary permeability in the isolated perfused rat lung. Exp Lung Res 1986;11:1-12.

27 Persson CGA. Plasma exudation in tracheobronchial and nasal airways: a mucosal defence mechanism become pathogenic in asthma and rhinitis. Eur Respir F 1990; 3:652-7s.

28 Morgan EH. Transferrin. In: Haeberli A, ed. Human protein data. Weinheim: VCH, 1 st instalment, 1992.

29 Cullen MR, Merrill WW. Association between neutrophil concentration in bronchoalveolar lavage fluid and recent losses in diffusing capacity in men formerly exposed to asbestos. Chest 1992;102:682-7.

30 Dunn MJ, ed. 2D electrophoresis: from protein maps to genomes. Electrophoresis 1995;16:1077-326. 